\title{
A late Würmian and Holocene pollen profile from Tüttensee, Upper Bavaria, evidence of 15 millennia of vegetation history in the Chiemsee glacier region
}

\author{
MANFRED RÖSCH ${ }^{1,2, *}$, ARNE FRIEDMANN ${ }^{3}$, SABINE RIECKHOFF $^{4}$, \\ PHILIPP STOJAKOWITS ${ }^{5}$ and DIRK SUDHAUS ${ }^{3}$
}

\author{
${ }^{1}$ Institute for Praehistoric and Protohistoric History and Western Asian Archaeology, Heidelberg, Germany \\ ${ }^{2}$ Baden-Württemberg State Office for Cultural Heritage, Hemmenhofen, Germany; \\ e-mail: manfred-roesch@t-online.de \\ ${ }^{3}$ Institute for Geography, University of Augsburg, Alter Postweg 118, D-86135 Augsburg, Germany; \\ e-mail: friedmann@geo.uni-augsburg.de; stojakowits@geo.uni-augsburg.de; dsudhaus@posteo.de \\ ${ }^{4}$ Institute for Praehistoric and Protohistoric History, University of Leipzig, Ritterstraße 14, 04109 Leipzig, \\ Germany; e-mail: sabine.rieckhoff@online.de \\ ${ }^{5}$ State Office for Mining, Energy and Geology, Stilleweg 2, 30655 Hannover, Germany
}

Received 14 July 2021; accepted for publication 2 December 2021

\begin{abstract}
A late Würmian and Holocene pollen profile from Tüttensee near Chiemsee, Bavaria, covering 14 millennia of vegetation history, shows the late Würmian reforestation of the area, Holocene woodland development, and later the human impact on the landscape. In the early Holocene a distinct Ulmus phase preceded the Corylus and Quercus expansion. Afterwards, between 6000 and 4000 BCE, Picea was most common. The expansion of Fagus and Abies started at 4000 BCE, together with the decline of Ulmus. Fagus was more common than Abies. From 500 BCE Abies started to decline, Fagus has also declined from 1000 CE onwards. Before the modern times Picea/Pinus phase Quercus is prevailing. The prehistoric human impact is rather weak. A short reforestation phase at $\sim 1 \mathrm{BCE}-1 \mathrm{CE}$ hints at the rather complex migration history in this region with so called Celts, Germanic people and Romans involved. Strong human impact indicated by cereals, Plantago lanceolata, other human indicators and deforestation started at $900 \mathrm{CE}$.
\end{abstract}

KEYWORDS: Late Würmian, Holocene, vegetation history, human impact, southeastern Bavaria

\section{INTRODUCTION}

Compared to adjacent regions in the west and southeast, there are only a few modern palynological studies in southern Bavaria (Fig. 1). Apart from pioneer work by Paul and Ruoff (1927, 1932), Langer (1958, 1959, 1962), Schmeidl (1971, 1972, 1977, 1980), Dieffenbach-Fries (1981), and Hohenstatter (1984), there were investigations in the region of the Inn-Chiemsee glacier (Rausch, 1975;

\footnotetext{
Corresponding author
}

Voigt, 1996; Fig. 1), near Rosenheim (Beug, 1976), at Ammersee (Kleinmann, 1995), in the Ammergebirge (Bludau, 1985), in mires around the Auerberg (Küster, 1988), at Pilsensee (Küster, 1995), in eastern Allgäu (Stojakowits, 2014), near Ingolstadt (Peters, 2011; Peters and Peters 2011), and in mires at the Yew forest of Paterzell near Weilheim (Rösch, 2021). The majority of these studies focused on peat deposits and not on lake sediments. However, lake records are well-suited to register 


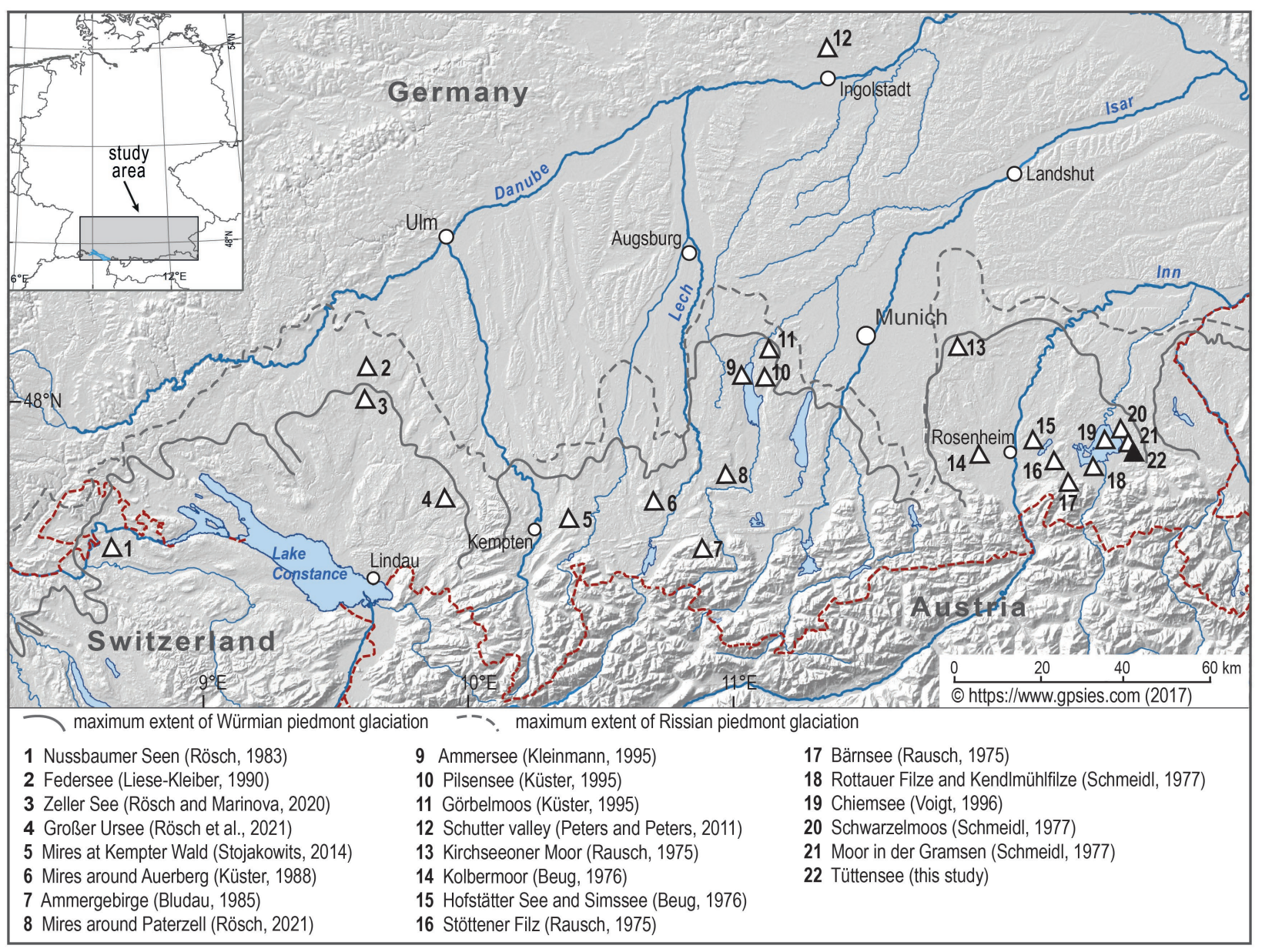

Fig. 1. Study area and situation of the pollen profiles discussed

past changes of vegetation and human impact (Rösch et al., 2021a). Concerning southern Bavaria, only a few lakes have been studied based on pollen analyses so far. Unfortunately, these records lack a robust age chronology and were subsampled at 5 to $10 \mathrm{~cm}$ intervals (e.g. Kleinmann, 1995; Voigt, 1996), providing insights into the vegetation history of these areas. Human impact (following Behre, 1981) was also detected in these studies, but due to low sample resolution and lacking age chronology, registered vegetation changes were restricted. Therefore, we analysed a $650 \mathrm{~cm}$ long core with subsamples from 2 to $4 \mathrm{~cm}$ from a small lake, called Tüttensee, east of Lake Chiemsee. Here we report the palynogical results from this high-resolution well-dated record in conjunction with archaeological evidence. Additionally, the hypothesis that Tüttensee originated from a meteorite impact dating 500 BCE (Ernstson et al., 2010) is also reviewed.

\section{STUDY AREA}

Following the Würmian, the retreat of Chiemsee glacier left behind a moraine landscape with many lakes. The Chiemsee is the largest of these lakes, covering an area of 7990 ha. The considerably smaller Tüttensee (10.8 ha) is situated $\sim 4 \mathrm{~km}$ south-east of the south-eastern corner of Chiemsee, near the mouth of Tiroler Achen $\left(12^{\circ} 34^{\prime} \mathrm{E}, 47^{\circ} 51^{\prime} \mathrm{N}, 523 \mathrm{~m}\right.$ a.s.l.). The kettle hole lake has a maximum length of $420 \mathrm{~m}$, a maximum width of $260 \mathrm{~m}$ and a maximum depth of $17 \mathrm{~m}$ (Wasserwirtschaftsamt Traunstein, 2021). The lake is surrounded by mires originating from advancing a marginal shallow littoral lake. The lake is eutrophic and belongs to the communities of Grabenstätt and Vachendorf, county of Traunstein in the region Chiemgau, Upper Bavaria. It is surrounded by wetlands and forest on all sides except for the south-east where arable land and predominantly grassland with single farms adjoin. But even the forests are not in a natural state. The village of Grabenstätt is located at a distance of $\sim 2 \mathrm{~km}$ to the west and north. The potential 
natural vegetation would be deciduous forest dominated by Fagus sylvatica. The actual vegetation is strongly influenced by agriculture and forestry. The climate is sub-oceanic, with an annual average temperature of $\sim 8^{\circ} \mathrm{C}$ and an annual precipitation of $1600 \mathrm{~mm}$ (Bayerisches Landesamt für Umwelt, 2012).

Recent detailed glacial morphological studies concluded, that Tüttensee did not originate as an impact crater of a meteorite (Huber et al., 2020). Our investigations also contradict clearly the meteorite hypothesis: we found a complete and undisturbed sediment sequence covering the late Würmian and Holocene without any hints of big fires documented by charcoal concentrations in the Iron Age. Tüttensee is a typical kettle hole lake that originated during ice recession towards the end of the last glaciation. Reflecting on initial investigations by Maizels (1992) the morphological Tüttensee depression and surrounding wall should rather be classified as a "rimmed kettle" or "crater kettle" type of glacial melt out kettle hole. See also the comparable work on kettle holes of Götz et al. (2018) in nearby Austria.

\section{MATERIAL AND METHODS}

\section{SEDIMENT CORE SAMPLING AND DATING}

The studied sediment core was obtained near the northern border of the lake (N 47 $50^{\prime} 52.5^{\prime \prime}$; E $12^{\circ} 34^{\prime} 09^{\prime \prime}$ using a Russian peat sampler with a chamber length of $50 \mathrm{~cm}$ and a diameter of $5 \mathrm{~cm}$. The complete core had a length of $650 \mathrm{~cm}$. The lithology is given in Table 1 . The chronology is based on ten AMS ${ }^{14} \mathrm{C}$ dates measured on terrestrial plant macrofossils (Table 2). The age/depth model was calculated using Oxcal 4.3 (Bronk Ramsey, 2009). Nine of the 10 dates could be used, because one accidentally dated sample was a recent root and gave a false age. Additionally, we constructed a simple visual age model based on interpolation (Fig. 2). The results of the ${ }^{14} \mathrm{C}$ measurements given in Table 2 were calibrated using the IntCal20 calibration curve (Reimer et al., 2020) and the CALIB 8.2 software.

\section{POLLEN ANALYSIS}

The core was subsampled for pollen analysis in intervals of 2 to $4 \mathrm{~cm}$ resulting in a total of $200 \mathrm{sam}$ ples. The preparation for pollen analysis was done using ultrasound sieving with a mesh size of $315 \mu \mathrm{m}$, partly with HCL, KOH, and SPT treatment after adding Lycopodium spore pellets. Each sample was analysed to a sum of 600 tree pollens. The identification and nomenclature of pollen follow Beug (2004), and that of spores Moore and Webb (1978). All charcoals $>10 \mu \mathrm{m}$ were registered. The pollen sum includes all terrestrial pollen except Cyperaceae, aquatics, spores of mosses, and pteridophytes. The pollen zones were defined visually and checked by cluster analysis and broken stick model calculations (Kasim and Raudenbush, 1998), resulting in identical zones. The pollen diagram (Fig. 3) was calculated using the software Tilia 2.1.1 (Grimm, 1984). The description of pollen zones follows Bastin (1979).

\section{RESULTS}

The percentages of selected taxa are shown in Figure 3. Twelve local pollen assemblage zones (LPAZs) could be described (Table 3 ).

At the base, the Bølling/Allerød-Interstadial complex can be identified in pollen zone 1 with a low resolution. Betula is dominating, but the

Table 1. Lithology of the Tüttensee profile

\begin{tabular}{|c|c|c|c|c|}
\hline $\begin{array}{l}\text { Depth } \\
\text { (cm below } \\
\text { surface) }\end{array}$ & Material & $\begin{array}{c}\text { Other } \\
\text { components }\end{array}$ & Colour & Remarks \\
\hline $0-6$ & Fully decomposed peat & Roots & Dark brown & Not sampled \\
\hline $7-39$ & Fen peat, strongly decomposed & Cyperaceae & Dark brown & - \\
\hline $40-53$ & Lake marl & conchilia & Grey-brown & Phragmites, Carex fruits \\
\hline $53-196$ & Fen peat, moderately decomposed & Wood, Phragmites & Dark brown & Wood of Alnus, Betula, Pinus \\
\hline $196-213$ & Lake marl & Conchilia & Ochre-brown & - \\
\hline $213-217$ & Peaty gyttja & Conchilia, wood & Dark brown & - \\
\hline $217-231$ & Lake marl with clay & Conchilia, wood & Ochre-grey & Organic layer at $222 \mathrm{~cm}$ \\
\hline $231-234$ & Peaty gyttja & Conchilia, wood & Dark brown & - \\
\hline $234-360$ & Lake marl & Conchilia & Ochre-grey & $260 \mathrm{~cm}:$ Frangula alnus \\
\hline $361-376$ & Fine detritus gyttja & Conchilia, wood & Dark brown & 362: wood \\
\hline $376-428$ & Lake marl & Conchilia & Dark grey & With organic mud \\
\hline $428-580$ & Lake marl & Minerogenic & Grey & Few conchilia \\
\hline $581-625$ & Lake marl & With silt and clay & Grey & Compact, few conchilia \\
\hline $625-642$ & Lake marl & With clay & Light grey & Compact, few conchilia \\
\hline $642->650$ & Lake marl & With fine sand & Light grey & Compact, very few conchilia \\
\hline
\end{tabular}


Table 2. Radiocarbon dates

\begin{tabular}{r|cccc}
\hline \hline No. & $\begin{array}{c}\text { Depth [cm] } \\
\text { mean }\end{array}$ & $\begin{array}{c}\text { Lab nr. } \\
\text { MAMS- }\end{array}$ & Age BP & $\begin{array}{c}\text { Age BCE/CE } \\
2 \sigma\end{array}$ \\
\hline 1 & 46 & 44013 & $517 \pm 17$ & $1405-1435$ AD \\
2 & 70 & 45758 & $1969 \pm 20$ & $6-86$ AD \\
3 & 116 & 45759 & $3685 \pm 24$ & $2143-2016$ BC \\
4 & 155 & 44014 & $4366 \pm 22$ & $3026-2910$ \\
5 & 186 & 47137 & $5786 \pm 21$ & $4709-4580$ \\
6 & 362 & 44015 & $8649 \pm 27$ & $7728-7592$ \\
7 & 401 & 45760 & $(5499 \pm 23)$ & $(4369-4325)$ \\
8 & 476 & 45761 & $9250 \pm 30$ & $8564-8334$ \\
9 & 519 & 47138 & $9506 \pm 26$ & $8859-8710$ \\
10 & 603 & 44016 & $11085 \pm 30$ & $11144-10971$ \\
\hline
\end{tabular}

percentages of herbs, especially Artemisia and grasses, are still high. Weak, but distinct maxima of Juniperus and Hippophaë are visible.

Subsequently, after the decrease of Betula and non-arboreal taxa, Pinus dominates the pollen spectrum with values of $60-80 \%$ in two millennia, covering the late Allerød and Younger Dryas (pollen zone 2).

In pollen zone 3 , the values of Pinus slowly decrease and those of Betula increase, with two peaks at the beginning and towards the end of this zone. The NAP percentages are low. The curves of first Ulmus and later Corylus and Tilia increase. The curve of Picea is continuous and increases slowly. This zone corresponds to the Preboreal.

In pollen zone 4, Pinus and Betula frequencies decrease further; Ulmus and Tilia remain on the same level, but Corylus and later Quercus levels increase. Corylus becomes the dominating pollen type with vales of $40-50 \%$. This zone encompasses the Boreal.

At the beginning of pollen zone 5, Corylus registers peak distribution, decreases afterwards, but is dominating during the whole zone. Tilia reaches its maximum representation and Fraxinus increases, as well as Picea. Ulmus, Quercus, and Picea are subdominant. The values of Betula and Pinus decline below $20 \%$. Zone 5 corresponds to the older part of the Atlantic.

In pollen zone 6, Corylus, Quercus, Ulmus, and Picea are codominant. Tilia still has a proportion of $10 \%$, and Fraxinus reaches its highest recorded levels. The NAP sum increases slightly. Among them are anthropogenic indicators like Plantago lanceolata, Rumex, Artemisia, and, towards the end, a single grain of Triticum. The zone belongs to the younger part of the Atlantic and dates between 5950 and 3925 BCE.

The rather short pollen zone 7 shows a dominance of Quercus. Ulmus, Tilia, and

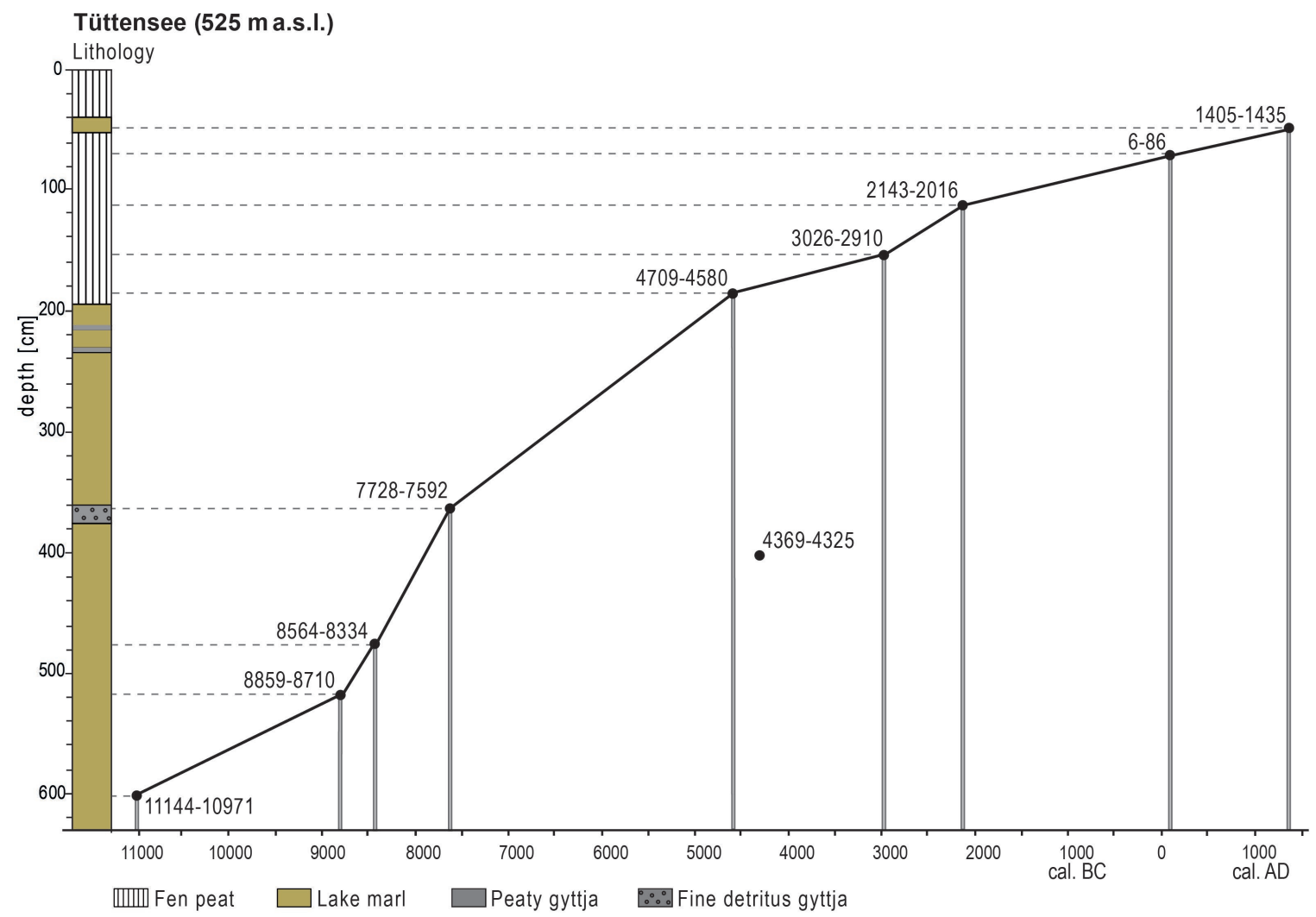

Fig. 2. Lithology and time model of the profile Tüttensee 
Table 3. Description of pollen zones

\begin{tabular}{r|cllcc}
\hline \hline No. & Firbas & \multicolumn{1}{c}{ Zone name } & \multicolumn{1}{c}{ Event } & $\begin{array}{c}\text { Upper } \\
\text { limit [cm] }]\end{array}$ & $\begin{array}{c}\text { Age } \\
{[\mathrm{BCE} / \mathrm{CE}]}\end{array}$ \\
\hline 12 & $\mathrm{Xb}$ & Picea-Pinus & Upper end of core & 7 & 1950 \\
11 & $\mathrm{Xa}$ & Fagus-Quercus & Picea $>15 \%$ & 27 & 1730 \\
10 & $\mathrm{IX}$ & Fagus & Quercus $>10 \%$ & 55.5 & 940 \\
9 & VIII/IX & Fagus-Abies-Corylus & Corylus $<10 \%$ & 78.5 & -340 \\
8 & VIII & Fagus-Abies & Fagus $<35 \%$ & 122.5 & -2235 \\
7 & VII & Quercus & Abies $>10 \%$ & 177 & -3480 \\
6 & VI/VII & Picea-Corylus-Quercus-Ulmus & Ulmus $<10 \%$ & 197 & -3925 \\
5 & VI & Corylus-Ulmus-Quercus & Corylus $<20 \%$ & 289 & -5950 \\
4 & V & Corylus-Pinus-Ulmus & Pinus $<20 \%$ & 429 & -8133 \\
3 & IV & Pinus-Betula-Ulmus & Corylus $>20 \%$ & 509 & -9070 \\
2 & III & Pinus & Ulmus $>1 \%$ & 562 & -10130 \\
1 & Ibc/II & Betula & Pinus $>30 \%$ & 640 & -11810 \\
\hline
\end{tabular}

Corylus frequencies decrease. Abies and Fagus appear and start to spread. The NAP sum is unchanged, and human indicators remain low. The zone belongs to the late Atlantic and the beginning of the Subboreal and dates between 3925 and 3480 BCE.

Pollen zone 8 corresponds to the early Subboreal and dates between 3480 and 2235 BCE. Fagus is predominant; Abies and Picea are subdominant. The curve of Carpinus is continuous. NAP is more common at the beginning and towards the end. Human indicators are more common; their curves are now sub-continuous.

Pollen zone 9, dating between 2235 and 340 BCE, has decreased Fagus values, but slightly increased Corylus percentages. Towards the end, there is a weak increase of Abies percentages. Except for an increase of Artemisia, the NAP and human indicators remain on the same low level. The zone covers the late Subboreal and early Subatlantic.

Pollen zone 10, dating from $340 \mathrm{BCE}$ to $940 \mathrm{CE}$ and, therefore, still belonging to the early Subatlantic, has enduring predominance of Fagus and is characterised by a strong decrease of Abies representation, recovering slightly towards the end of the zone. Betula values are slightly increased. Human indicators remain on the same level.

In pollen zone 11, dating from 940 to 1730 CE (late Subatlantic), NAP and human indicators increase conspicuously. Fagus is still dominating, but its curve is slightly decreasing. Here Quercus is subdominant. Abies is sparsely distributed here, but Juniperus and Corylus counts increased.

In pollen zone 12 , from 1730 to $1950 \mathrm{BCE}$, the curves of most deciduous trees, as well as
NAP decrease suddenly, together with a strong expansion of Pinus, Picea, and Betula.

\section{DISCUSSION}

\section{LATE WÜRMIAN, EARLY AND MIDDLE HOLOCENE VEGETATION HISTORY}

The profile covers the most of the late Würmian and the Holocene. The origin of the lake as a meteoritic impact crater dating into the Iron Age can therefore be excluded. The late Würmian sequence at the base seems incomplete: Whereas the Oldest Dryas with open steppe to tundra vegetation and therefore dominance of NAP was not covered by the core, the phase of dominant shrubs with Juniperus and Hippophaë is most probably lacking because of a hiatus. The rest of the late Würmian sequence is typical for elevations below $800 \mathrm{~m}$ a.s.l. in southern Germany and surrounding pre-Alpine areas such as Lobsigensee, Nussbaumer Seen, Durchenbergried, Langegger Filz, Kulzer Moos, or Federsee (Lang, 1994). The landscape was covered by rather sparse Pinus forest. A decrease of trees during the Younger Dryas is not detectable. A second establishment of Betula during the Preboreal is a widespread phenomenon along the northern fringes of the Alps. Afterwards, the history is different from regions further to the west: there is an expansion of Ulmus and later Tilia before the main spread of Corylus. The Ulmus curve exceeds $10 \%$ already before $10000 \mathrm{BCE}$, the Tilia curve $5 \%$ before $9000 \mathrm{BCE}$. The mass expansion of Corylus starts hardly before 9000 BCE. The maximum values of Corylus are recorded with $40 \%$, less than at most sites in the Rhine glacier 


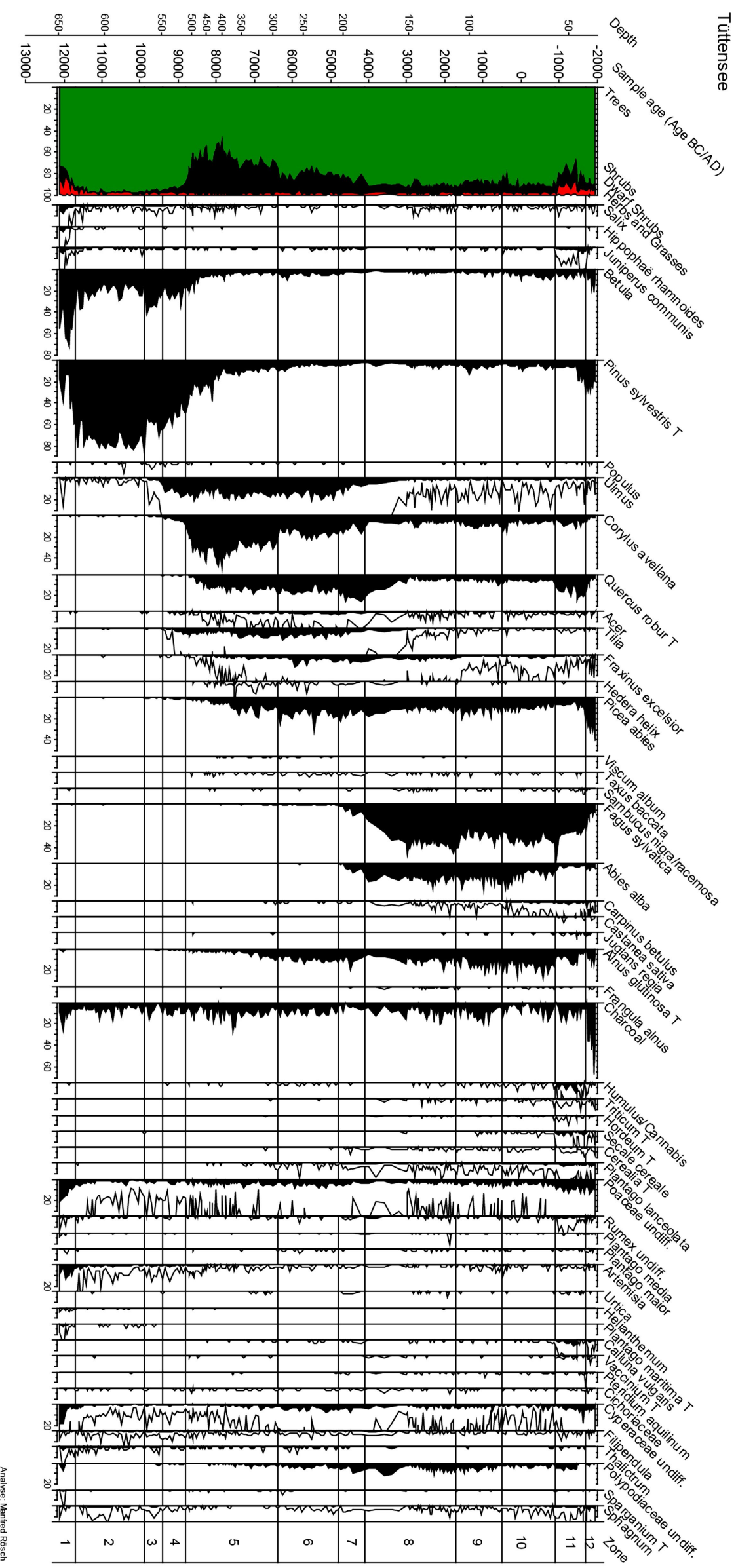

Fig. 3. Tüttensee, Pollen, spores, and micro-charcoals 
area. But at Großer Ursee, located between the Rhine and Iller glaciers, Corylus remains also below 50\% (Rösch et al., 2021b) due to increasing continentality towards the east.

First anthropogenic forest disturbances occur between 6000 and $5000 \mathrm{BCE}$, most probably caused by Mesolithic or even Early Neolithic groups (Kossack and Schmeidl, 1974/75).

The early expansion and high importance of Ulmus is another typical feature of the Würmian glaciated Bavarian Alpine foreland (Küster, 1990, 1995). The Ulmus decline starts shortly before $4000 \mathrm{BCE}$, synchronously to many other regions of the Alpine foreland, and is a rather long-lasting process, terminating at $\sim 3000 \mathrm{BCE}$. The recession of Tilia and Fraxinus starts somewhat later, after $4000 \mathrm{BCE}$, coinciding with the spread of Fagus and Abies. At the same time, Picea values decline, and Quercus reaches maximum distribution between 4200 and 3500 BCE. Apart from a continuous curve of Plantago lanceolata, human indicators remain weak. There is also, in contrast to the Rhine glacier region, no increase of Corylus levels and charred particles, which would indicate Late Neolithic slashand-burn agriculture. Between 4000 and 3000 $\mathrm{BCE}$, corresponding to the Younger, Late and Final Neolithic, during the 1st phase of Quercus dominance, when Fagus and Abies expanded, there is again woodland disturbance, now with clear evidence of human impact.

\section{HUMAN IMPACT \\ AND THE ANTHROPOCENE}

A Quercus expansion and the decline of Picea, Ulmus, and Tilia frequencies are difficult to explain as natural woodland development or by a climatic change. Therefore, we would like to stress some kind of human impact, which is to be expected during the Younger and Late Neolithic, as visible in many pollen profiles of the northern pre-Alpine lowlands, for example Pilsensee (Küster, 1995), around Auerberg (Küster, 1988), Federsee (Liese-Kleiber, 1990, 2016), in Upper Svabia and at Lake Constance (Rösch et al., 2021). Promotion of Quercus is typical for the Bronze Age, the Iron Age and medieval woodland management known as "Mittelwaldwirtschaft", a forest management system working with two tree layers, an upper layer consisting of old oaks and a lower layer cut down every three decades (Bärnthol, 2003). But this kind of forest management is not proved for the Neolithic. From a woodland management preferring Quercus, wood pasture with pigs would benefit. Therefore, it would be interesting if studies of Neolithic animal bones would support this idea.

Between $3000 \mathrm{BCE}$ and $1000 \mathrm{CE}$, the landscape remained densely forested, with Fagus as the dominant taxon, accompanied by Picea, and Abies, the latter getting rarer from 300 $\mathrm{BCE}$ onwards. The rather weak human impact in the Bronze Age and the Iron Age and deforestation are perhaps caused by the situation of the profile in the always forested fringes of the lake where upland pollen was filtered out to a high degree (Fyfe et al., 2013).

Carpinus is never abundantly represented. Some secondary Corylus peaks occur, which, together with charcoal peaks, may indicate small-scale shifting cultivation or at least coppice forestry. These peaks date to 3000,1000 and $500 \mathrm{BCE}$, corresponding to the Final Neolithic, Late Bronze and Late pre-Roman Iron Age. Similar Corylus peaks of the same age are also visible in pollen diagrams at Zeller See in Upper Swabia (Rösch and Marinova, 2021).

Recently Bronze Age and particularly Iron Age interruptions of land use, indicated by reforestation initiated by Betula and other pioneers, draw attention (Müller, 1962; Rieckhoff and Rösch, 2019). In the Tüttensee profile there are longer lasting phases with higher Betula percentages, indicating coppice forestry, particularly in the 6th and 5th millennia BCE, and from 500 BCE onwards, but only a few weak and short Betula peaks occur, perhaps indicating abandoned fields, at 900, 720, 270, 135-90 BCE and $1 \mathrm{CE}$, and a last one at 610 CE. Primarily they indicate local events like the abandonment of nearby fields or villages.

Of particular interest are the Betula peaks of the Late Iron Age due to their (pre)historical background: at $\sim 100$ BCE the Celtic population of Southern Germany started to leave their fortified urban settlements (oppida), open villages and rural estates (Rieckhoff, 2007). However, the land did not remain abandoned for long as it was occupied by different Germanic people. In Bavaria we could identify the South-Eastern Bavarian group (SOB group), which came from Thuringia (Rieckhoff, 1993, 1995). This SOB group no longer encountered the Celts but used their abandoned land, often at the same places as their forerunners whose former fields were still recognisable on the basis of a pioneer woodland with a lot of 
Betula. Finally, the SOB group disappeared, as well, not later than $40 \mathrm{BCE}$. A Celtic land abandonment is likewise visible in all pollen profiles in south-west Germany, however the immigrants are not known so well as in Bavaria (Rieckhoff and Rösch, 2019).

If those profiles are compared with Tüttensee in the Chiemgau, it is doubtful whether history followed the same course here. Chiemgau is the name of the region around the Chiemsee between the rivers Inn and Salzach. In Roman times the Inn marked the border between the province of Raetia on the left and the province of Noricum on the right side of the river. This may perhaps explain why the local (Celtic?) population (Alauni?) of the Chiemgau stayed longer than the Celts west of the Inn, and why the SOB group, immigrating in the 1st third of the 1st century BCE, either settled alongside them or even partly mixed with them. Whatever kind of coexistence of the two different ethnic people we should imagine, in the end all inhabitants left the Chiemgau at any rate not later than $40 \mathrm{BCE}$. According to the archaeological record, if we follow the revisited new chronology (Rieckhoff, 1995; Rieckhoff and Rösch, 2019) of the scarce single and settlement finds (Zanier, 2004: 239), this was the end of permanent settlement in the region until the Romans came. As in Raetia as well, effective emigration occurred in this time period which probably caused an interruption of land use as indicated by the Betula peak (20 BCE - $20 \mathrm{CE}$ ). Consequently, when the Romans arrived, they probably met a dense forest dominated by Fagus.

The most important Celtic settlement in the Chiemgau was Stöffling, Lkr. Traunstein, $\sim 10 \mathrm{~km}$ north of Tüttensee, unequivocally dated from the 3rd to the middle of the 1st century BCE (Irlinger, 1990). Its successor was the nearby vicus Bedaium-Seebruck at the north shore of the Chiemsee, also the earliest Roman foundation in the Chiemgau at 50 CE (Keller, 1981). Some objects, pottery and brooches, point to a Celtic forerunner of Roman Seebruck, existing at the same time as Stöffling, i.e. until $40 \mathrm{BCE}$ at most (Irlinger, 2004). In view of the undisputed hiatus until the Roman occupation, some construction timber (Quercus) finds from the long-term excavations at Seebruck, dated by dendrochronology rather precisely between $6 \mathrm{BCE}$ and $8 \mathrm{CE}$, were quite unexpected (Burmeister, 1998). Such an early Roman guard after the conquest at $15 \mathrm{BCE}$ can be explained by the location of Seebruck at the main traffic route along the Alps from west (Bregenz, Lake Constance) to east (Salzburg). Unfortunately, there is no relationship between the timber and any archaeological object therefore we have only this date but nothing more. Consequently, the constructor of this presumed rack is still doubtful. However, it is not necessary to assume an isolated military post stimulating the land use which must have totally declined before, when the Celtic and Germanic groups had left. Thus, even a Roman rack would not contradict the Betula peak (20 BCE - $20 \mathrm{CE})$.

Medieval deforestation started rather late, in the 10th century $\mathrm{CE}$, and is, compared to other profiles, rather weak with NAP values below $15 \%$, which again could be explained by the filter effect of the lakeshore vegetation. Partial clearing of the wetland forest is indicated by a decline of Alnus and an increase of Cyperaceae and Poaceae, the latter indicating, together with an increase of Juniperus, intense forest pasturing.

\section{LAKE LEVEL FLUCTUATIONS AND CLIMATE}

Several lake level fluctuations are recorded in the Tüttensee profile (Table 1). Evidence for low water levels includes the deposition of peat or shallow water sediments above lake marl. From a certain point onwards, after $\sim 4000$ BCE, silting-up developed so far, that peat accumulation became the normal process. Deep water levels could have been no longer recorded, but very high water levels, when again lake marl formation instead of peat accumulation took place. This was the case at a profile depth between 53 and 40 $\mathrm{cm}$, corresponding to 1090 to $1567 \mathrm{CE}$, covering the most parts of the Little Ice Age and some time before. Lower water levels developed at $~ 7760-7650$ BCE, 4750-4670 BCE and 4360-4280 BCE. The first two lower lake levels covering the late Atlantic period were also detected at Nussbaumer Seen (Rösch, 1983), at Federsee (Liese-Kleiber, 1990), and at Ammersee (Kleinmann, 1995). At Federsee and Ammersee other lower water stands were recorded during the Subboreal, whereas at Tüttensee a long-lasting rather low water level existed throughout almost the entire Subboreal period up to the Middle Ages. Only in the medieval period and the Modern Age, between 1090 and $1560 \mathrm{CE}$ the lake level record shows 
a last strong rise with precipitation of lake marl. Lake level fluctuations could be caused by climatic change (Liu et al., 2008). The pollen curves show no clear correlation to the lake level. Perhaps the increase of Alnus corresponding with a deep level at $7300 \mathrm{BC}$, and the increase of Cyperaceae corresponding with the high lake level from $1000 \mathrm{AD}$ onwards can be considered exceptions.

\section{THE ORIGIN OF TÜTTENSEE}

Ernstson et al. (2010) postulated that the origin of the Tüttensee was caused by a large meteorite impact at $~ 500 \mathrm{BCE}$ in the Celtic period. From a glaciological point of view, the hollow of Tüttensee is related to dead ice which was cut off from the Inn-Chiemsee glacier during the ice decay after the Last Glacial Maximum (LGM) (e.g. Ganss, 1977; Doppler and Geiss, 2005; Huber et al., 2020). Our results support the glaciological explanation because of the following reasons:

1 . The vegetation history documented by sediments and their pollen content started already in late Glacial times at 12000 BCE.

2 . There are no disturbances or any intercalations in the fen peat of our profile which could be assigned to an impact of a meteorite into the lake. Furthermore, no significant charcoal peak was detected $\sim 500 \mathrm{BCE}$, nor local vegetation responded in any unusual way, nor a hiatus occurred.

3. If a meteorite impact during the Iron Age created Tüttensee, all sediments older than Iron Age would be lacking, which is not the case.

Therefore, the meteorite impact hypotheses must be rejected.

\section{SUMMARY AND CONCLUSION}

A $6.5 \mathrm{~m}$ thick littoral profile of Tüttensee, consisting of lake marl in the lower parts and an alternation of peat and lake marl in the upper part was studied by pollen analysis and dated with 10 radiocarbon dates, nine of which could be included into the time model. The lithological sequence covers chronologically most parts of the late Würmian and the Holocene. The results indicate that the lake is of glacial origin and not created by a meteorite impact during the pre-Roman Iron Age. The Holocene vegetation history shows some differences to regions further to the west or east: Ulmus spread earlier than Corylus. Quercus was the third established thermophilous taxon. The main expansion of Picea and Tilia started synchronously at $7500 \mathrm{BCE}$. The rise of Fagus and that of Abies as forest components were again synchronous, starting after 5000 BCE. This coincides with the Ulmus decline and a Fagus maximum. Fagus was the dominant tree from $3500 \mathrm{BCE}$ to $1700 \mathrm{CE}$. Afterwards, Picea and Pinus have been dominating. Apart from a few single earlier grains, human indicator pollens (Cannabis/Humulus, Triticum type, Hordeum type, Cerealia undiff., Plantago lanceolata, Rumex, Plantago media and major, Artemisia, Urtica, Calluna vulgaris) occur regularly from 4000 BCE onwards, corresponding to the Younger Neolithic, but remained rather sparse during prehistory, getting abundant at $900 \mathrm{CE}$ when also a strong deforestation took place. Low water levels could be detected based on changes of the sediment type during the late Atlantic and early Subboreal. Afterwards, fen peat was accumulated until a steep rise in water level, mostly during the late medieval period, when again lake marl was deposited.

\section{ACKNOWLEDGEMENTS}

We thank the owner of Tüttensee, Freiherr von Frede, for the coring permission.

\section{REFERENCES}

Bärnthol, R., 2003. Nieder- und Mittelwald in Franken. Waldwirtschaftsformen aus dem Mittelalter. Schriften und Kataloge des Fränkischen Freilandmuseums 40, Fränkisches Freilandmuseum, Bad Windsheim.

Bastin, B., 1979. Essai de définition d'une terminologie précise applicable au commentaire des diagrammes polliniques se rapportant au quaternaire. Bulletin de la Societe Royale de Botanique de Belgique 112, $7-12$.

Bayerisches Landesamt für Umwelt, 2012. Potentielle Natürliche Vegetation Bayerns - Erläuterungen zur Übersichtskarte 1:500 000. LfU Bayern, Augsburg.

Behre, KE., 1981. The interpretation of anthropogenic indicators in pollen diagrams. Pollen et Spores 23, $225-245$.

Beug, H.J., 1976. Die spätglaziale und frühpostglaziale Vegetationsgeschichte im Gebiet des ehemaligen Rosenheimer Sees (Oberbayern). Botanische Jahrbücher fur Systematik 95(3), 373-400.

Beug, H.J., 2004. Leitfaden der Pollenbestimmung für Mitteleuropa und angrenzende Gebiete. Pfeil, München. 
Bludau, W., 1985. Zur Paläoökologie des Ammergebirges im Spät- und Postglazial. Schäuble, Rheinfelden.

Bronk Ramsey, C., 2009. Dealing with outliers and offsets in radiocarbon dating. Radiocarbon 51(3), 1023-1045.

Burmeister, S., 1998. Vicus und spätrömische Befestigung von Seebruck-Bedaium. Materialhefte zur bayerischen Vorgeschichte Reihe A - Fundinventare und Ausgrabungsbefunde 76, Lassleben, Kallmünz.

Dieffenbach-Fries, H., 1981. Zur spät- und postglazialen Vegetationsentwicklung bei Oberstdorf (Oberallgäu) und im Kleinwalsertal (Vorarlberg). Pollen- und makrofossilanalytische Untersuchungen an drei Mooren der montanen Stufe. Dissertation, TU Darmstadt.

Doppler, G., Geiss, E., 2005. Der Tüttensee im Chiemgau - Toteiskessel statt Impaktkrater. Bayerisches Landesamt für Umwelt, Available at: https://www.lfu.bayern.de/geologie/meteorite/bayern/doc/tuettensee.pdf.

Ernstson, K., Mayer, W., Neumair, A., Rappenglück, B., Rappenglück, M.A., Sudhaus, D., Zeller, K., 2010. The Chiemgau crater strewn field: evidence of a Holocene large impact event in southeast Bavaria, Germany. Journal of Siberian Federal University, Engineering and Technologies 1, 72-103.

Fyfe, R.M., Twiddle, C., Sugita, S., Gaillard, J.M., Barratt, P., Caseldine, C.P., Dodson, J., Edwards, K.J., Farrell, M., Froyd, C., Grant, M.J., Huckerby, E., Innes, J.B., Shaw, H., Waller, M. 2013. The Holocene vegetation cover of Britain and Ireland: overcoming problems of scale and discerning patterns of openness. Quaternary Science Reviews 73, 132148. https://doi.org/10.1016/j.quascirev.2013.05.014

Ganss, O., 1977. Geologische Karte von Bayern 1:25000, Erläuterungen zum Blatt Nr. 8140 Prien a. Chiemsee und zum Blatt Nr. 8141 Traunstein. Bayerisches Geologisches Landesamt, München.

Götz, J., Salcher, B., Starnberger, R., Krisai, R., 2018. Geophysical, topographic and stratigraphic analyses of perialpine kettles and implications for postglacial mire formation. Geografiska Annaler, Series A, Physical Geography 100(3), 254-271. https://doi.org/10.1080/04353676.2018.1446638

Grimm, E.C., 1984. Fire and other factors controlling the Big Woods vegetation of Minnesota in the midnineteenth century. Ecological Monographs 54, 291-311.

Hohenstatter, E., 1984. Geschichte und Stratigraphie des Murnauer Mooses. Jahrbuch des Vereins zum Schutze der Bergwelt 49, 163-192.

Huber, R., Darga, R., Lauterbach, H., 2020. Der späteiszeitliche Tüttensee-Komplex als Ergebnis der Abschmelzgeschichte am Ostrand des ChiemseeGletschers und sein Bezug zum „Chiemgau Impakt“ (Landkreis Traunstein, Oberbayern). E\&G Quaternary Science Journal 69, 93-120. https://doi. org/10.5194/egqsj-69-93-2020

Irlinger, W., 1990. Die keltische Siedlung in Stöffling. Das Archäologische Jahr in Bayern 1990, 76-79.
Irlinger, W., 2004. Zur Kontinuität von der Spätlatènezeit in die frühe römische Kaiserzeit in Südostbayern. In: Hüssen, C.-M., Irlinger, W., Zanier, W. (eds), Spätlatènezeit und frühe römische Kaiserzeit zwischen Alpenrand und Donau. Akten des Kolloquiums in Ingolstadt am 11. und 12. Oktober 2001. Bonn, 165-174.

Kasim, R.M., Raudenbush, S.W., 1998. Application of Gibbs Sampling to Nested Variance Components Models with Heterogeneous Within-Group Variance. Journal of Educational and Behavioral Statistics 23(2), 93-116.

Keller, E., 1981. Römisches und Keltisches aus Seebruck am Chiemsee, Gemeinde Seeon-Seebruck, Landkreis Traunstein, Oberbayern. Das Archäologische Jahr in Bayern 1981, 130-131.

Kleinmann, A., 1995. Seespiegelschwankungen am Ammersee. Ein Beitrag zur spät- und postglazialen Klimageschichte Bayerns. Geologica Bavarica 99, 253-367.

Kossack, G, Schmeidl, H., 1974/75. Vorneolithischer Getreidebau im bayerischen Alpenvorland. Jahresberichte der bayerischen Bodendenkmalpflege 15/16, 7-23.

Küster, H., 1988. Vom Werden einer Kulturlandschaft. Vegetationsgeschichtliche Studien am Auerberg (Südbayern). Quellen und Forschungen zur prähistorischen und provinzialrömischen Archäologie 3, 1-163.

Küster, H., 1990. Gedanken zur Entstehung von Waldtypen in Süddeutschland. Berichte der Reinhold-Tüxen-Gesellschaft 2, 25-43.

Küster, H., 1995. Postglaziale Vegetationsgeschichte Südbayerns. Geobotanische Studien zur prähistorischen Landschaftskunde. Akademie Verlag, Berlin.

Lang, G., 1994. Quartäre Vegetationsgeschichte Europas. Gustav Fischer, Jena, Stuttgart, New York.

Langer, H., 1958. Die Vegetationsgeschichte des Benninger Riedes und die Verknüpfung mit der Vegetationsgeschichte des Memminger Tales. Botanische Jahrbücher 77(4), 355-422.

Langer, H., 1959. Zur Waldgeschichte des „Großen Waldes” am Grünten (Allgäu). Botanische Jahrbücher 78(4), 489-497.

Langer, H., 1962. Beiträge zur Kenntnis der Waldgeschichte und Waldgesellschaften Süddeutschlands. Berichte der Naturforschenden Gesellschaft Augsburg 14, 1-120.

Liese-Kleiber, H., 1990. Züge der Landschafts- und Vegetationsentwicklung im Federseegebiet. Neolithikum und Bronzezeit in neuen Pollendiagrammen. Berichte der Römisch-Germanischen Kommission 71(1), 59-83.

Liese-Kleiber, H., 2016. Die Bronzezeit im Siedlungsraum des Federsees - Pollenanalysen zur Landschaftsentwicklung. Siedlungsarchäologie im Alpenvorland XIII, Forschungen und Berichte zur Vor- und Frühgeschichte in Baden-Württemberg 128. Darmstadt, pp. 63-131. 
Liu, X., Herzschuh, U., Shen, J., Jiang, Q., Xiao, X., 2008. Holocene environmental and climatic changes inferred from Wulungu Lake in northern Xinjiang, China. Quaternary Research 70(3), 412-425. https://doi.org/10.1016/j.yqres.2008.06.005

Maizels, J., 1992. Boulder ring structures produced during Jökulhlaup Flows: Origin and hydraulic significance. Geografiska Annaler, Series A, Physical Geography 74(1), 21-33.

Moore, P.D., Webb, J.A., 1978. An illustrated guide to Pollen Analysis. Hodder and Stoughton, London.

Müller, H., 1962. Pollenanalytische Untersuchung eines Quartärprofils durch die spät- und nacheiszeitlichen Ablagerungen des Schleinsees (Südwestdeutschland). Geologisches Jahrbuch 79, 493-526.

Paul, H., Ruoff, S., 1927. Pollenstatistische und stratigraphische Mooruntersuchungen im südlichen Bayern. I. Teil. Moore im außeralpinen Gebiet der diluvialen Salzach-, Cheimsee- und Inngletscher. Berichte der Bayerischen Botanischen Gesellschaft 17, pp. 1-84.

Paul, H., Ruoff, S., 1932. Pollenstatistische und stratigraphische Mooruntersuchungen im südlichen Bayern. II. Teil. Moore in den Gebieten der Isar-, Allgäu- und Rheinvorlandgletscher. Berichte der Bayerischen Botanischen Gesellschaft 20, pp. 1-264.

Peters, M., Peters A., 2011. Analyse eines Pollenprofils aus dem Schuttertal in Ingolstadt-Pettenhofen - Zur Rekonstruktion der vorgeschichtlichen Umwelt. Bericht der Bayerischen Bodendenkmalpflege 52, 19-46.

Peters, M., 2011. Pollenanalytische Untersuchungen zur Vegetationsgeschichte in Bayern zwischen der Donau und den Alpen seit der Jüngeren DryasZeit. Berichte der Reinhold-Tüxen-Gesellschaft (RTG) 23, 119-137.

Rausch, K.A., 1975. Untersuchungen zur spät- und nacheiszeitlichen Vegetationsgeschichte im Gebiet des ehemaligen Inn-Chiemseegletschers. Flora 164, 235-282.

Reimer, P., Austin, W., Bard, E., Bayliss, A., Blackwell, P., Bronk Ramsey, C., Butzin, M., Cheng, H., Edwards, R.L., Friedrich, M., Grootes, P.M., Guilderson, T.P., Hajdas, I., Heaton, T.J., Hogg, A.G., Hughen, K.A., Kromer, B., Manning, S.W., Muscheler, R., Palmer, J.G., Pearson, C., van der Plicht, J., Reimer, R.W., Richards, D.A., Scott, E.M., Southon, J.R., Turney, C.S.M., Wacker, L., Adolphi, F., Büntgen, U., Capano, M., Fahrni, S.M., Fogtmann-Schulz, A., Friedrich, R., Köhler, P., Kudsk, S., Miyake, F., Olsen, J., Reinig, F., Sakamoto, M., Sookdeo, A., Talamo, S., 2020. The IntCal20 Northern Hemisphere Radiocarbon Age Calibration Curve (0-55 cal kBP). Radiocarbon 62, 725-757. https://doi.org/10.1017/RDC.2020.41

Rieckhoff, S., 1993. Frühe Germanen in Südbayern. In: Dannheimer, H., Gebhard, R. (eds), Das keltische Jahrtausend. Mainz, pp. 237-242.

Rieckhoff, S., 1995. Süddeutschland im Spannungsfeld von Kelten, Germanen und Römern. Studien zur Chronologie der Spätlatènezeit im südlichen
Mitteleuropa. Trierer Zeitschrift Beiheft 19. Trier: 1995.

Rieckhoff, S., 2007. Wo sind sie geblieben? Zur archäologischen Evidenz der Kelten in Süddeutschland im 1. Jahrhundert v. Chr. In: Birkhan, H. (ed.), Kelten-Einfälle an der Donau. Akten des Vierten Symposiums deutschsprachiger Keltologinnen und Keltologen. Philologische - Historische - Archäologische Evidenzen, Linz/Donau, 17-21 Juli 2005. Wien, pp. 409-440.

Rieckhoff, S., Rösch, M., 2019. Ein keltischer Exodus? Archäologisch-botanische Überlegungen zum Übergang Eisenzeit - Römische Kaiserzeit in Südwestdeutschland. In: Karl, R., Leskovar, J. (eds), Interpretierte Eisenzeiten. Fallstudien, Methoden, Theorie. Tagungsbeiträge der 8. Linzer Gespräche zur interpretativen Eisenzeitarchäologie. Studien zur Kulturgeschichte von Oberösterreich 49, 57-87.

Rösch, M., 1983. Geschichte der Nussbaumer Seen (Kanton Thurgau) und ihrer Umgebung seit dem Ausgang der letzten Eiszeit aufgrund quartärbotanischer, stratigraphischer und sedimentologischer Untersuchungen. Mitteilungen der Thurgauischen Naturforschenden Gesellschaft 45, 1-110.

Rösch, M., 2021. 48. Mires near the yew forest of Paterzell (Upper Bavaria, Germany). Grana 60(2), 155157. https://doi.org/10.1080/00173134.2020.1767196

Rösch M., Marinova, E., 2021. 51. Zeller See. Grana 60(3), 243-246. https://doi.org/10.1080/00173134.2 020.1821765

Rösch, M., Feger, K.-H., Fischer, E., Hinderer, M., Kämpf, L., Kleinmann, A., Lechterbeck, J., Marinova, E., Schwalb, A., Tserendorj, G., Wick, L., 2021a. How changes of past vegetation and human impact are documented in lake sediments: paleoenvironmental research in southwestern Germany, a review. In: Rosen, M.R. et al. (eds), Limnogeology: Progress, Challenges and Opportunities, Syntheses in Limnogeology. Springer, pp. 107-134.

Rösch, M., Stojakowits, P., Friedmann, A., 2021b. Does site elevation determine the start and intensity of human impact? Pollen evidence from southern Germany. Vegetation History and Archaeobotany 30(2), 255-268. https://doi.org/10.1007/s00334-02000780-4

Schmeidl, H., 1971. Ein Beitrag zur spätglazialen Vegetations- und Waldentwicklung im westlichen Salzachgletschergebiet. Eiszeitalter und Gegenwart 22, 110-126.

Schmeidl, H., 1972. Zur spät- und postglazialen Vegetationsgeschichte am Nordrand der bayerischen Voralpen. Berichte der Deutschen Botanischen Gesellschaft 85, 79-82.

Schmeidl, H., 1977. Pollenanalytische Untersuchungen im Gebiet des ehemaligen Chiemseegletschers. In: Ganss, O. (ed.) Geologische Karte von Bayern 1:25000, Erläuterungen zum Blatt Nr. 8140 Prien a. Chiemsee und zum Blatt Nr. 8141 Traunstein. Bayerisches Geologisches Landesamt, München, pp. 239-264. 
Schmeidl, H., 1980. Die Moorvorkommen des Kartenblattes 8239 Aschau im Chiemgau. Zur spät- und postglazialen Vegetations- und Waldentwicklung in der montanen Stufe des Kartenblattes Aschau im Chiemgau. In: Ganns, O. (ed.) Geologische Karte von Bayern 1:25000, Erläuterungen zum Blatt Nr. 8239 Aschau im Chiemgau Bayerisches Geologisches Landesamt, München, pp. 111-132.

Stojakowits, P., 2014. Pollenanalytische Untersuchungen zur Rekonstruktion der Vegetationsgeschichte im südlichen Iller-Wertach-Jungmoränengebiet seit dem Spätglazial. Dissertation, Univ. Augsburg.

Voigt, R., 1996. Paläolimnologische und vegetationsgeschichtliche Untersuchungen an Sedimenten aus Fuschlsee und Chiemsee (Salzburg und Bayern). Dissertationes Botanicae 270, 1-303.
Wasserwirtschaftsamt Traunstein, 2021. Gewässerportraits-Tüttensee. URL: www.wwa-ts.bayern.de/ fluesse_seen/gewaesserportraits/tuettensee

Zanier, W., 2004. Gedanken zur Besiedlung der Spätlatène- und frühen römischen Kaiserzeit zwischen Alpenrand und Donau. Eine Zusammenfassung mit Ausblick und Fundstellenlisten. In: Hüssen, C.-M., Irlinger, W., Zanier, W. (eds), Spätlatènezeit und frühe römische Kaiserzeit zwischen Alpenrand und Donau. Akten des Kolloquiums in Ingolstadt am 11. und 12. Oktober 2001. Bonn: 2004, 239. 